\title{
NATURALLY OCCURRING AND SYNTHETIC IMMUNOMODULATORS WITH DIFFERENT BIOLOGICAL ACTIVITIES: LITERATURE SURVEY AND HISTORICAL INSIGHT
}

\author{
Anas Ramadan Abdel-Sattar ${ }^{1}$, Mohamed Ayman El-Zahabi ${ }^{1 *}$, Abdallah E. Abdallah ${ }^{1}$ \& \\ Hazem Elkady ${ }^{1}$ \\ ${ }^{1}$ Department of Pharmaceutical Medicinal Chemistry \& Drug Design, Faculty of Pharmacy \\ (Boys), Al-Azhar University, Cairo, Egypt \\ * Corresponding author :malzahaby@azhar.edu.eg
}

\begin{abstract}
An immunomodulator is a substance that stimulates or suppresses the immune system and may help the body fight cancer. The aim of this review is to highlight results of research done on immunomodulators of natural or synthetic origin showing different biological activities. The selection of papers was made using the most relevant scaffolds based on their immunomodulatory biological results. The review also discussed the different synthetic methods for various immunomodulatory drugs such as CC-122. The results showed that many drugs incorporating different scaffolds such as quinazolines revealed promising results for immunomodulatory therapeutic purposes. This work shall hopefully encourage researchers to undertake further work on design and synthesis of new potential immunomodulatory candidates.
\end{abstract}

Keywords: Immunomodulation, Immunosuppressants, Immunostimulants, Thalidomide, Immunoadjuvants, Immunity, Immune system, Transplantation. 


\section{Immunomodulation:}

\subsection{Introduction:}

Immune system is a remarkably sophisticated defense system within vertebrates, to protect them from invading agents. It is able to generate varieties of cells and molecules capable of recognizing and eliminating limitless varieties of foreign and undesirable agents. Modulation of the immune system denotes to any change in the immune response that can involve induction, expression, amplification or inhibition of any part or phase of the immune response (Bomford, 2010).

Thus, immunomodulator is a substance that stimulates or suppresses the immune system and may help the body fight cancer, infection, or other diseases. They are two types; specific immunomodulating agents, such as monoclonal antibodies, cytokines, and vaccines, affect specific parts of the immune system, and nonspecific immunomodulating agents, such as Bacillus Calmette-Guérin (BCG) and levamisole, affect the immune system in a general way. Also called immune system modulator (Institute, 2021).

Immunopharmacology is a comparatively new and developing branch of pharmacology aims at searching for immunomodulators. The potential uses of immunodulators in clinical medicine include the reconstitution of immune deficiency (e.g. the treatment of AIDS) and the suppression of normal or excessive immune function (e.g. the treatment of graft rejection or autoimmune disease) (Saroj et al., 2012).

Specific immunomodulators administered together with antigens known as immunological adjuvants to boost the immune response to the vaccine constituents. For instance, a plant origin saponin used in veterinary medicine whereas, the non- specific immunostimulators offer a generalized state of resistance to pathogens or tumors. Fungal product cyclosporin A selectively block the function of $\mathrm{T}$ lymphocyte and used to prevent graft rejection (Bomford, 2010).

\subsection{Immunity:}

It refers to the ability of the body to identify and resist microorganisms that are potentially harmful. This ability enables the body to fight or prevent infectious disease and inhibit tissue and organ damage. The immune system is not confined to any one part of the body. Immune stem cells, formed in the bone marrow, may remain in the bone marrow until maturation or migrate to different body sites for maturation. After maturation, most immune cells circulate into the body and exert specific effects (Naga Preethi and Rajeshwari). The immune system has two distinct, but overlapping, mechanisms which help to fight invading organisms:

- Cell-mediated defences (cellular immunity)

- Antibody-mediated defences (humoral immunity) 
Cell-mediated immunity (CMI): It is the result of the activity of many leukocyte actions, reactions, interactions that range from simple to complex. This type of immunity is dependent on the actions of the $\mathrm{T}$ (Thymus) lymphocytes, which are responsible for a delayed type of immune response. The $\mathrm{T}$ lymphocyte becomes sensitized by its first contact with a specific antigen (Weiner, 2015).

Humoral (antibody-mediated) immunity: In humoral immunity special lymphocytes (white blood cells), called B (Bone cell) lymphocytes, produce circulating antibodies to act against a foreign substance. This type of immunity is based on the antigen-antibody response (Susan FM) (Figure 1).

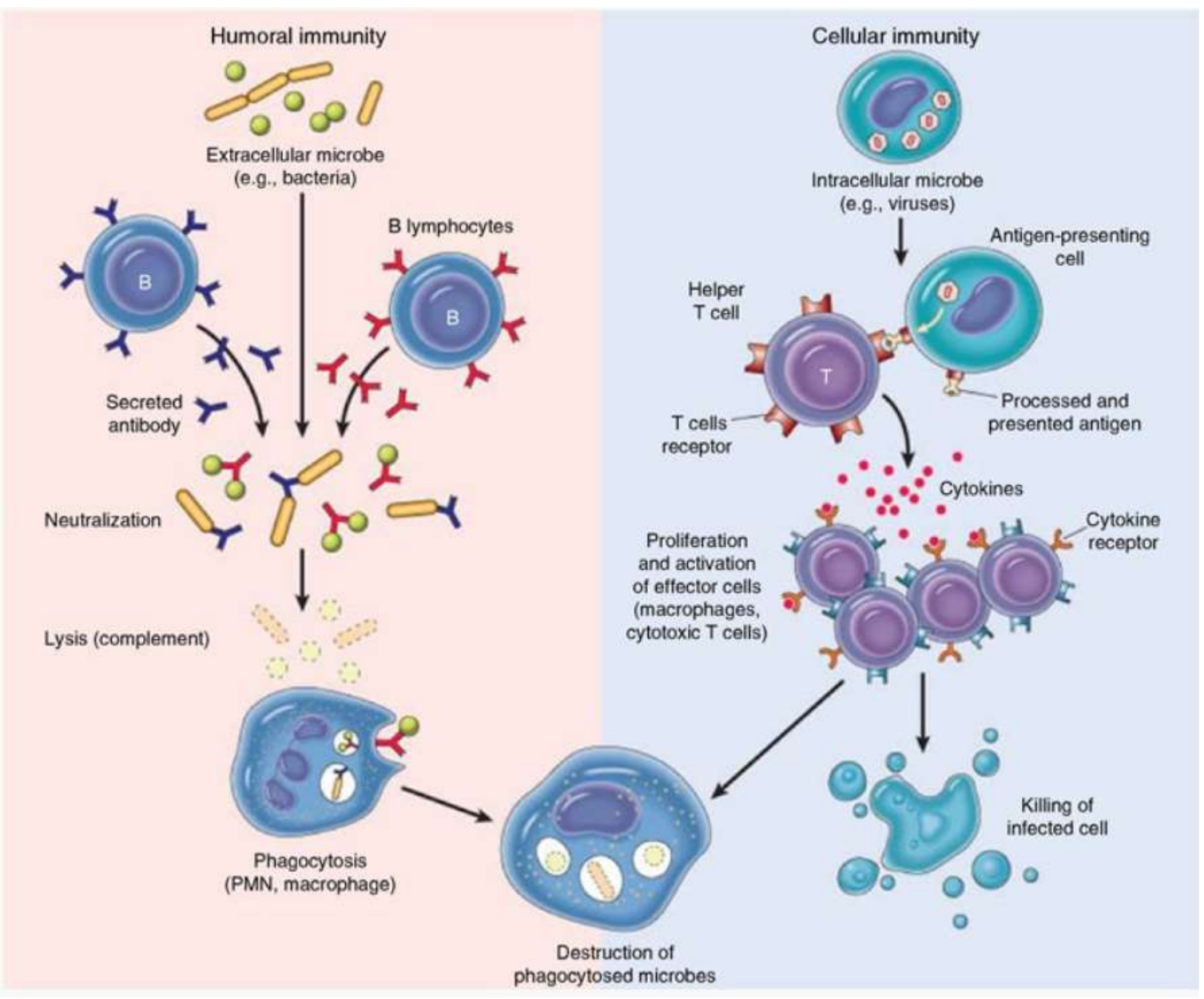

(Figure 1); Antibody-mediated immunity vs. cell mediated immunity (Nagata, 2009).

\subsection{Immune system:}

The immune system is composed of many interdependent cell types that collectively protect the body from bacterial, parasitic, fungal, viral infections and from the growth of tumor cells. Many of these cell types have specialized functions. The cells of the immune 
system can engulf bacteria, kill parasites or tumor cells, or kill viral-infected cells. Often, these cells depend on the $\mathrm{T}$ helper subset for activation signals in the form of secretions formally known as cytokines, lymphokines, or more specifically interleukins (Parham, 2014).

\subsubsection{The Innate Immune System}

Innate immunity comprises a series of host defenses including barrier function, cytokines, complement, phagocytes, natural killer (NK) cells, and gamma-delta (gd) T cells to provide the initial (nonspecific) response to a pathogen or injury (Kumar et al., 2011a). These responses are phylogenetically ancient and have been developed to cope with pathogens that are encountered regularly but that rarely cause disease (Weiner, 2015). Unlike the adaptive(specific) immune system, responses are generic and leave no memory; nonetheless the innate immune system functions effectively to keep organisms healthy. Indeed a failing in innate immunity is hypothesized to contribute to secondary infections in critical illness and death in sepsis (Hotchkiss and Nicholson, 2006). Stimulation of the active components of the innate immune system occurs by way of pathogen-associated molecular pattern (PAMP) receptors or damage-associated molecular pattern (DAMP) receptors. PAMPs are recognized by membrane bound or vesicular pathogen recognition receptors (PRRs) including the Toll-like receptors (TLRs), nucleotide binding oligomerization domain (NOD)-like receptors, and retinoic acid inducible gene (RIG)-like

receptors. Bacteria stimulate these PRRs to activate various intracellular signaling cascades, leading to a pro-inflammatory response. For example,the gram-negative bacterial endotoxin, lipopolysaccharide, binds to TLR 4, whereas the gram-positive peptidoglycan binds to TLR 2 In the setting of tissue damage from an infection or trauma, DAMPs activate the innate immune system through these PRRs. Indeed there is significant overlap in mechanisms stimulated by PAMPs and DAMPs. As sedatives are frequently administered during infection and surgery, investigation of their immune effects on these mechanisms of immune stimulation would seem prudent (Saroj et al., 2012).

\subsubsection{The Adaptive Immune System}

Adaptive or acquired immunity differs from the innateresponse as it is specific, has an element of memory, and is unique to vertebrates. The humoral component involves the proliferation of antigen-stimulated B lymphocytes into antibody-secreting plasma cells. The cellular component is mediated by $\mathrm{T}$ lymphocytes, the predominant cell types being helper $\mathrm{T}$ cells $(\mathrm{Th})$ and cytotoxic $\mathrm{T}$ cells. Recently, regulatory $\mathrm{T}$ cells that likely dampen the immune response have been identified (Ademokun and Dunn-Walters, 2010). T cells recognize antigens bound to major histocompatibility complex (MHC) proteins by way of $\mathrm{T}$ cell receptors that are antigen specific. Th lymphocytes act through secretion of cytokines to elaborate and prime the immune response. This action includes inducing immunoglobin class switching of B cells, activation of Tc, and optimization of bactericidal capacity of phagocytes. Th lymphocytes are characterized by expression of CD4 proteins and are activated when MHC type II molecules, expressed on professional antigen-presenting cells 
(dendritic cells, macrophages, and B cells), activate the specific $\mathrm{T}$ cell receptor (Gombart et al., 2020).Th1 cells are regarded as pro-inflammatory secreting cytokines such as interferon$\mathrm{g}$ and interleukin (IL)-12, and stimulate macrophage function and cytotoxic $\mathrm{T}$ cell function. Th2 cells have an anti-inflammatory phenotype and secrete cytokine such as IL-4 and IL-10, acting cooperatively to activate B cells. Further, Th cells include the regulatory $\mathrm{T}$ cells that act to dampen the immune response and the Th17 class that modulates neutrophil function. A shift from Th1 to Th2 cells has been observed in the latter stages of sepsis, possibly induced by the apoptotic cell death of lymphocytes, and the subsequent anti-inflammatory phenotype has been associated with secondary infections in these patients (Hotchkiss and Nicholson, 2006).

\subsection{Immunomodulators:}

Immunomodulators are substances that have been shown to modify the immune systems response to a threat upon it. They modulate and potentiate the weapons of your immune system keeping them in a highly prepared state for any threat it may encounter (Weiss and Dahlke, 2019). With this balancing effect, all subsequent immune responses improve (Aziz et al., 2013). When your immune system is in this highly prepared state, the invading organisms do not have the time to build up force and strength before the immune system attacks, destroys and/or weakens the invader (Kushwaha, 2012). Immunomodulation is the process of modifying an immune response in a positive or negative manner by administration of adrug or compound. Many proteins, amino acids, and natural compounds have shown a significant ability to regulate immune responses, including interferon- $\gamma$ (IFN- $\gamma$ ) (Hill and Sarvetnick, 2002, Szekeres-Bartho et al., 2001), steroids (Abo-Zena and Horwitz, 2002, Roberts et al., 1996), DMG . These are biological or synthetic substances, which can stimulate, suppress or modulate any of the immune system including both adaptive and innate arms of the immune response. Clinically immunomodulators can be classified into following three categories (Arya and Gupta, 2011).

\subsubsection{Immunoadjuvants:}

These agents are used for enhancing vaccines efficacy and therefore, could be considered specific immune stimulants (Arya and Gupta, 2011), example in this regard is of Freund's adjuvant (Billiau and Matthys, 2001). The immunoadjuvants hold the promise of being the true modulators of immune response. It has proposed to exploit them for selecting between cellular and humoral, Th1 (helper T1 cells) and Th2, (helper T2 cells) immunoprotective and immunodestructive, and reagenic (IgE) versus immunoglobin $\mathrm{G}$ ( $\mathrm{IgG}$ ) type of immune responses, which poses to be a real challenge to vaccine designers (Arya and Gupta, 2011). 


\subsubsection{Immunostimulants:}

These agents are inherently non- specific in nature as they envisaged to enhance body's resistance against infection. They can act through innate immune response and through adaptive immune response (Billiau and Matthys, 2001). In healthy individuals the immunostimulants are expected to serve as prophylactic and promoter agents i.e. as immunopotentiators by enhancing basic level of immune response, and in the individual with impairment of immune response as immunotherapeutic agents (Ford and Roach, 2009).

\subsubsection{Immunosuppressants:}

These are a structurally and functionally heterogeneous group of drugs, which are often concomitantly administered in combination regimens to treat various types of organ transplant rejection and autoimmune diseases (Ford and Roach, 2009).

\subsection{Examples of immunosuppressant in literature:}

These drugs have major role in organ transplantation and auto immune diseases. The drugs are:

\subsubsection{Calcineurin inhibitors (Specific T-cell inhibitors)}

\subsubsection{Cyclosporine (Ciclosporin):}

Cyclosporine (1) is a lipophilic cyclicpolypeptide composed of 11 amino acids. The drug is extracted from a soil fungus. It profoundly and selectively inhibits Tymphocyte proliferation, IL2 and other cytokine production and response to inducer T-cells. Lymphocytes are arrested in G0 to G1 phase. Cyclosporine is used to prevent rejection of kidney, liver and cardiac allogeneic transplanted (Yu and Sun, 2013). Discovery and pharmacological development of cyclosporine was conducted by Jean Borel and colleagues in the 1970s.

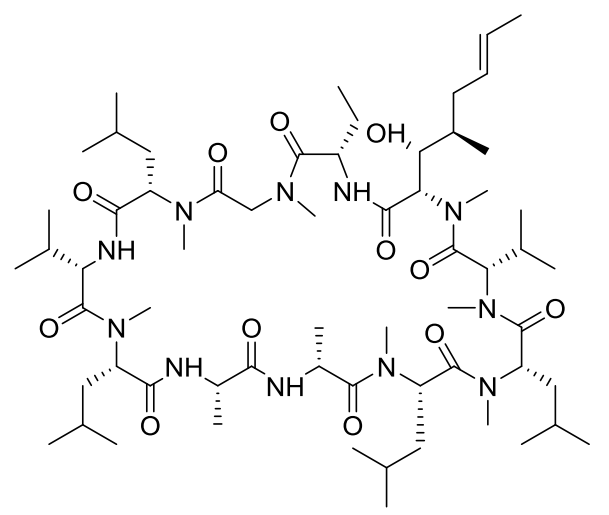

Cyclosporine (1) 
Cyclosporine is the first compound to inhibit the lymphocytes specifically and reversibly, and represents the prototype of a new generation of immunosuppressive drugs (Colombo and Ammirati, 2011). An obvious dose-response relationship for the antiproliferative effects of cyclosporine was detected. $\mathrm{IC}_{50}$ determined with concanavalin $\mathrm{A}$ was $46 \mathrm{n} M$ for cyclosporine against Whole blood samples collected from 10 healthy adult domestic shorthair cats (Kyles et al., 2000).

\subsubsection{Tacrolimus (TAC):}

Tacrolimus (2) is a newer immunosuppressant, macrolide. TAC exerts its immunosuppressive effect in the same manner as CSA except that it binds to a different immunophillin, FKBP-12 (fk-binding protein). Tacrolimus is used in prevention of rejection of liver and kidney and is given with a corticosteroids and antimetabolites (Sommerauer et al., 2014). An obvious dose-response relationship for the antiproliferative effects of tacrolimus was detected. $\mathrm{IC}_{50}$ determined with concanavalin A was $9 \mathrm{n} M$ for tacrolimus against Whole blood samples collected from 10 healthy adult domestic shorthair cats (Kyles et al., 2000).

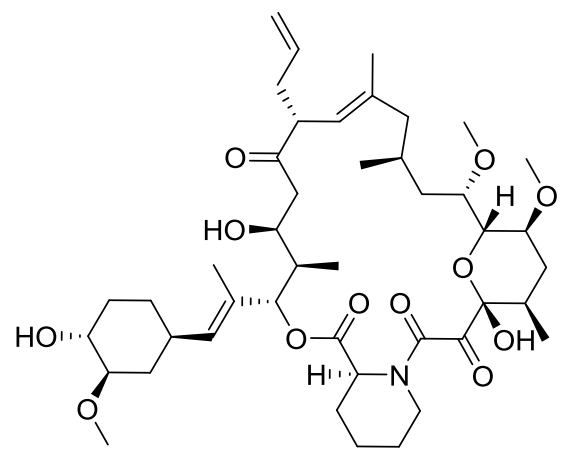

Tacrolimus(2)

\subsubsection{Antiproliferative drugs (Cytotoxic drugs)}

\subsubsection{Azathioprine:}

Azathioprine (3) is a purine analogue with cytotoxic and immunosuppressive activity. Its selective uptake into immune cells and intracellular conversion to the active metabolite 6-mercaptopurine, which then undergoes further transformation to inhibit de novo purine synthesis and damage to DNA. It is approved for prevention of renal and other graft rejection (Coordination). $\mathrm{IC}_{50}$ determined with concanavalin A was $1.3 \pm 0.4 \mu \mathrm{M}$ for 6-mercaptopurine against Whole blood samples (Nafe et al., 2014). 


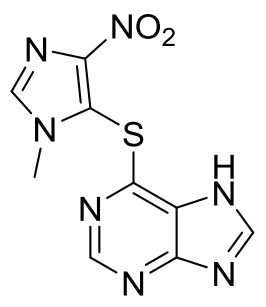

Azathioprine(3)

\subsubsection{Cyclophosphamide:}

Cyclophosphamide (4) is a drug has more effect on B- cells and humoral immunity compared to that on T-cells and cell- mediated immunity. It is used in bone marrow transplant (Spelman et al., 2006). The $\mathrm{IC}_{50}$ of cyclophosphamide was $2.1 \mathrm{mM}$ against Human embryonic palatal mesenchymal (HEPM) cells (Tsuchiya et al., 1988).<smiles>O=P1(N(CCCl)CCCl)NCCCO1</smiles>

\section{Cyclophosphamide(4)}

\subsubsection{Methotrexate:}

Methotrexate (5) inhibits dihydrofolate reductase, which results in accumulation of inactive oxidized folates and cessation of nucleotide synthesis. This activity primarily kills cells that are in S-phase (DNA synthesis); non-proliferating cells are resistant. Methotrexate also inhibits macrophage activation, as demonstrated in an animal model of adjuvant arthritis (Cronstein and Aune, 2020). The anti-malarial activity of the anti-cancer drug methotrexate against chloroquine-sensitive T9-96 and the multidrug-resistant K1 strains of Plasmodium falciparum was assessed in vitro. Mean $\mathrm{IC}_{50}$ values of $0.32+/-0.05$ $\mathrm{nM}$ and $48.02+/-4.40 \mathrm{nM}$ were obtained for T9-96 and $\mathrm{K} 1$, respectively, indicating methotrexate's high potency against both sensitive and resistant P. falciparum strains in vitro (Dar et al., 2008).<smiles>CN(Cc1cnc2nc(N)nc(N)c2n1)c1ccc(C(=O)N[C@@H](CCC(=O)O)C(=O)O)cc1</smiles>

Methotrexate (5) 


\subsubsection{Glucocorticoids}

\subsubsection{Prednisolone:}

The steroids are used to suppress acute rejection of solid allograft and in chronic graft versus hostdisease. The steroids are able to rapidly reduce lymphocyte populations by lysis or redistribution. On entering cells, they bind to the glucocorticoid receptor and the complex passes into the nucleus and regulates the translation of DNA (Krensky et al., 2011). Prednisolone (6) was granted FDA approval on 21 June 1955. IC I0 $_{50}$ (concentration of drug that gave 50\% inhibition of cell growth) values of prednisolone were 580.0 (1037.9) $\mathrm{nM}$ against mitogen-induced blastogenesis of human peripheral blood mononuclear cells in-vitro (Sugiyama et al., 2001).

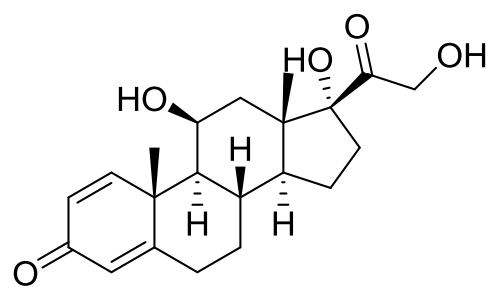

Prednisolone(6)

\subsubsection{Antibodies}

\subsection{Muromonab:}

CD3-muromonab is a murine monoclonal antibody against the CD3 glycoprotein located near to the $\mathrm{T}$ cell receptor on helper $\mathrm{T}$ cells. It is used for treatment of acute rejection of renal allografts as well as cardiac and hepatic transplantation (Becker, 2007).

\subsection{Antithymocyte globin (ATG):}

It is a polyclonal antibody purified from horse or rats immunized with human thymic lymphocytes. It binds to T-lymphocytes and depletes them. It is a potent immunosuppressant used for suppress acute allograft reject episodes (Dzuris et al., 2012).

\subsection{Examples of immunostimulant drug in literature:}

They stimulate the immune system to fight against immunodeficiencies (like AIDS), infections and cancers. 


\subsubsection{Levamisole:}

Levamisole (7), a synthetic low molecular weight compound, is the first member of a new class of drugs which can increase the functions of cellular immunity in normal, healthy laboratory animals. The properties of levamisole have contributed to improved understanding of the molecular events which mediate or trigger immune responses (Muller et al., 1999). Levamisole an anthelmintic drug that also restores functions of $B$ lymphocytes, $\mathrm{T}$ lymphocytes, monocytes and macrophages. Hence it has been used in colon cancer along with 5-FU (Sajid et al., 2006). Levamisole can act either as an immunostimulant agent or an immunosuppressive agent. These apparently paradoxical effects depend upon the dose administered, the timing of its administration, the experimental assay used to measure effects, and the host genetic background (Muller et al., 1999).

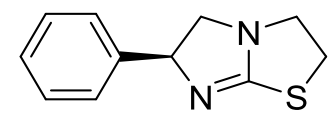

\section{Levamisole(7)}

\subsubsection{Thalidomide and its analogues:}

Cancer cells are weak immunogenic so that drugs which are able to co-stimulate Tcells can enable immune system to respond and eradicate the cancer cells without affecting normal cells (El-Zahabi et al., 2020). Thalidomide (8) and its analogues e.g. lenalidomide (9) and pomalidomide (10) are examples for such drugs (Bartlett et al., 2004).<smiles>O=C1CCC(N2C(=O)c3ccccc3C2=O)C(=O)N1</smiles>

Thalidomide (8)<smiles>Nc1cccc2c1CN(C1CCC(=O)NC1=O)C2=O</smiles>

Lenalidomide (9)<smiles>Nc1cccc2c1C(=O)N(C1CCC(=O)NC1=O)C2=O</smiles>

Pomalidomide (10)

Thalidomide and its analogues appears to be a multi-target drug that impinges on a number of seemingly distinct cellular processes, including peptidase inhibition, glucosidase inhibition, androgen receptor antagonism and (cyclooxygenase) COX inhibition (Sano et al., 2005).

One of the most studied biological activities influenced by thalidomide is the inhibition of the expression of the pro-inflammatory cytokine tumor necrosis factor (TNF $\square$ ) (Bartlett et al., 2004). TNF is a central regulator of the inflammatory cascade that controls many effector pathways as anti-angiogenic, anti-inflammatory and immunomodulatory molecule. The molecular mode of action of thalidomide on TNF $\square$ expression is thought to involve the inflammatory $\mathrm{NFjB}$ signaling pathway, specifically inhibiting the activity of the IjB kinase, IKKa (Keifer et al., 2001). Thalidomide, 
pomalidomide and lenalidomide have a TNF $\square \square \mathrm{IC}_{50}$ of 200, 13, $100 \mathrm{nM}$ respectively in LPS stimulated PBMC (Muller et al., 1999).

Thalidomide is also known as an inhibitor of nuclear factor kappa B (NF-kB) activation (De-Blanco et al., 2007, Majumdar et al., 2002). NF-kB is a family of structurally related transcription factors that play a major role in inflammation and immune responses. Moreover, NF-kB inhibits apoptosis, and induces proliferation and angiogenesis, suggesting that $\mathrm{NF}-\mathrm{kB}$ has a pivotal role in oncogenesis and tumor progression (Cerundolo et al., 2009).

\section{Synthesis of Lenalidomide:}

Lenalidomide (9) was synthesized following the synthetic route of Muller et al. (Muller et al., 1999), shown in Scheme 1. It was obtained from the $N \alpha$-(tertbutoxycarbonyl)-L-glutamine and the methyl-2-methyl-3-nitrobenzoate in five steps with an overall yield of $18 \%$.<smiles>CC(C)(C)CC(=O)NC1CCC(=O)NC1=O</smiles><smiles>[Y][C@H](C)O[C@H]1CC[C@H](N2Cc3c(cccc3[N+](=O)[O-])C(=O)N2)C(=O)N1</smiles>

Scheme 1

Lenalidomide(9)

Scheme 1. Reagents and conditions: (I) CDI, DMAP, toluene, reflux, $12 \mathrm{~h}$; 65\%; (II) $\mathrm{HCl}$ $1 \mathrm{~N}$, THF, rt, $12 \mathrm{~h}$; quant; (III) NBS, AIBN, CCl4, reflux, $24 \mathrm{~h}$; 49\%; (IV) 3aminopiperidine-2,6-dione, TEA, MeCN, 55 C, 18 h; 57\%; (V) H2, Pd/C, MeOH, DMF; quant.

\subsubsection{CC-122 (avadomide $($ )):}

2 It was reported that, CC-122 (11) (avadomide $®$ ), a new chemical entity termed pleiotropic pathway modifier, has potent anti-proliferative, immunomodulatory and anti-angiogenic activities with a potentially broader range of activity than lenalidomide (9) (Hagner et al., 2014). CC-122 showed promising results in phase I clinical trials for diffuse large B-cell lymphoma (DLBCL), MM and solid tumor (Ito et al., 2010). It was well tolerated with favorable response rates and durable remission in phase I B study on patients with B-cell Non-Hodgkin Lymphoma (NHL)(Ito et al., 2010). CC-122 Has 
Robust Anti-Proliferative Activity in a Primary Chronic Lymphocytic Leukemia (CLL) Co-Culture Model with $\mathrm{IC}_{50}$ of CC-122 1.2 $\mu \mathrm{M}$ (Blocksidge et al., 2014).<smiles>Cc1nc2cccc(N)c2c(=O)n1C1CCC(=O)NC1=O</smiles>

CC-122 (11)

CC-122 (avadomide $®)$ (11) was synthesized following the synthetic route of Hagner et al (Hagner et al., 2015), shown in scheme 2.<smiles>Nc1cccc([N+](=O)[O-])c1C(=O)O</smiles>

(i)<smiles>Cc1nc2cccc([N+](=O)[O-])c2c(=O)o1</smiles><smiles></smiles><smiles></smiles><smiles>[GeH2]</smiles><smiles>CC(C)(N)c1cccc([N+](=O)[O-])c1C(=O)NC1CCC(=O)NC1=O</smiles><smiles>C=CC=O</smiles><smiles>Cc1nc2cccc([N+](=O)[O-])c2c(=O)n1C1CCC(=O)NC1=O</smiles>

\section{CC-122}

scheme 2

Synthesis of cc-122: (i) acetic anhydride, $120{ }^{\circ} \mathrm{C}$; (ii) water, reflux; (iii) 3-amino-2,6piperidinedione hydrochloride, diisopropylethylamine, hydroxybenzotriazole, 1-ethyl-3-(3dimethylaminopropyl)carbodiimide, N,N-dimethylformamide; (iv) chlorotrimethylsilane, triethylamine, acetonitrile, $75^{\circ} \mathrm{C}$ and then deuterium oxide, room temperature; and (v) $\mathrm{H}$, $\mathrm{Pd}(\mathrm{OH}) 2, \mathrm{~N}, \mathrm{~N}$-dimethylformamide.

\subsubsection{CC-220 (Iberdomide):}

CC-220 (12) (Iberdomide) is the most recent immunomodulatory drug developed for the treatment of relapsed/refractory MM (RRMM) and systemic lupus erythematosus (SLE). CC-220 has improved efficacy to degrade IKZF1 and IKZF3 through tighter binding to the CRL4 ${ }^{\mathrm{CRBN}}$ E3 ligase (Matyskiela et al., 2018). 


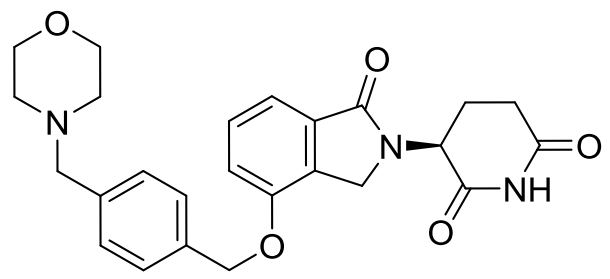

CC-220 (12)

Iberdomide biochemical potency translates into greater anti-MM activity than lenalidomide or pomalidomide in both IMiD-sensitive and -resistant MM cell lines. These results provide strong preclinical and translational evidence for iberdomide activity and its potential for clinical development in MM in combination with other agents, especially with bortezomib and daratumumab in RRMM. Cereblon-binding affinity $\mathrm{IC}_{50}$ of iberdomide is $\sim 150 \mathrm{nM}$ (Bjorklund et al., 2020).

\subsection{Immunomodulation by fungal toxins}

\subsubsection{Aflatoxins:}

Aflatoxin (13) is an immunomodulating agent that acts primarily on cell-mediated immunity and phagocytic cell function. In addition to further characterization of aflatoxin induced immunotoxicity in various species, some recent studies have focused on ameliorating the effects of aflatoxin by supplementing or amending the diet (Bondy and Pestka, 2000). Dillapiol was isolated from the essential oil of dill as a specific inhibitor of aflatoxin $\mathrm{G}_{1}$ production. It inhibited aflatoxin $\mathrm{G}_{1}$ production by Aspergillus parasiticus with an $\mathrm{IC}_{50}$ value of $0.15 \mu \mathrm{M}$ without inhibiting aflatoxin $\mathrm{B}_{1}$ production or fungal growth (Razzaghi-Abyaneh et al., 2007).

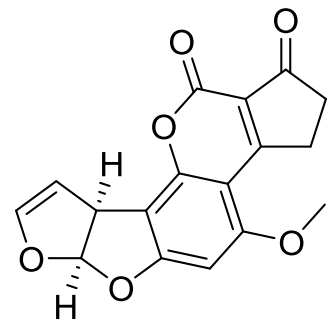

Aflatoxin (13)

\subsubsection{Ochratoxins:}

Ochratoxins (14) are fungal secondary metabolites produced during storage by fungus of the genera Aspergillus, mainly in tropical and warmer regions and by Penicillum verrucosum, in temperate and colder areas (Pohland et al., 1992; Varga et al., 1996). The most commonly occurring and most toxic member is ochratoxin A (OTA) (Hagelberg et al., 1989; Peckham et al., 1971). OTA was described as modulator of humoral and cellular 
immunity, inflammation, nitrosative stress and gut immunity. The $\mathrm{IC}_{50}$ values for cytotoxicity measured by neutral red uptake were $1.10 \mu \mathrm{M}$ in the midbrain cells and 1.05 $\mu \mathrm{M}$ in the limb bud cells. The $\mathrm{IC}_{50}$ values of cell differentiation were $1.10 \mu \mathrm{M}$ in the midbrain cells and 1.0 $\mu \mathrm{M}$ in the limb bud cells (Hong et al., 2000). OTA is able to modulate the immune response, with important implications for human and animal health (Marin and Taranu, 2015).<smiles>C[C@@H]1Cc2c(Cl)cc(C(=O)N[C@@H](Cc3ccccc3)C(=O)O)c(O)c2C(=O)O1</smiles>

Ochratoxin (14)

\subsubsection{Gliotoxin:}

Gliotoxin (15) is a member of the epipolythiodioxo-piperazine (ETP) class of toxins. gliotoxin suppresses innate immunity in invasive aspergillosis, particularly by compromising neutrophils, but the underlying molecular mechanisms remain elusive (König et al., 2019). Gliotoxin exhibits antifungal, antiviral as well as strong immunosuppressive activities (El Enshasy, 2011). The immunosuppressive effects of gliotoxin have been explained by different mechanisms. It suppresses cell activity and induces apoptosis in a variety of cell types including neutrophils, eosinophils and granulocytes (Ward et al., 1999). Gliotoxin inhibited proliferation of six breast cancer cell lines in culture with mean \pm SD IC $_{50} 289 \pm 328 \mu \mathrm{M}$ intracellular farnesylation of Lamin B and geranylgeranylation of Rap1A were inhibited in a dose-dependent manner (Vigushin et al., 2004).

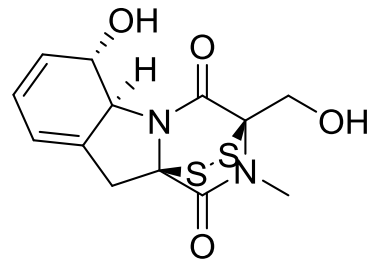

Gliotoxin (15)

\subsubsection{Mizoribine:}

The immunosuppressive antibiotic mizoribine (MZA) (16) was first isolated from the culture medium of Eupenicillium brefeldianum isolated from soil samples on Hachijo island (Japan; Mizuno et al. 1974) (Mizuno et al., 1974). Based on the immunosuppressive 
mechanism of mizoribine, mizoribine is superior to many other clinically used drugs, since it may not cause damage to normal cells and nucleic acids (Yokota, 2002).<smiles>NC(=O)c1ncn([C@@H]2O[C@H](CO)[C@@H](O)[C@H]2O)c1O</smiles>

\section{Mizoribine (16)}

\subsubsection{Myriocin:}

Myriocin (17) was first isolated from the thermopholic fungus Myriococcum albomyces by Kluepfel and his group in 1972. The compound was recognized as an active antibiotic against yeasts and dermatophytes when applied in vitro. However, the compound appeared to be too toxic for therapeutic purposes in humans (Kluepfel et al., 1975).

Myriocin was found to suppress both the production of antibodies against red blood cells of sheep and the induction of cytotoxic T-lymphocytes more strongly than cyclosporine A. Myriocin was 10- to 100-fold more effective than cyclosporin a both in in vivo and in vitro tests (SASAKI et al., 1994).

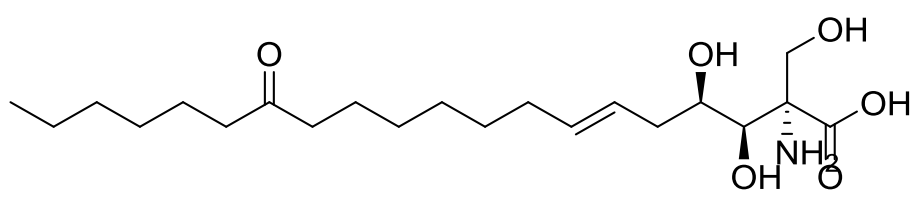

Myriocin (17)

\subsubsection{Fingolimod:}

Fingolimod (18) is a novel immunosuppressant obtained by chemical modification of myriocin (Adachi et al., 1995). It is prolongs the survival of allo-graft transplants and is effective in the treatment of some immunological diseases. Not least, this compound may have a great clinical potential because of efficacy as oral drug for the treatment of multiple sclerosis (Klatt et al., 2007).

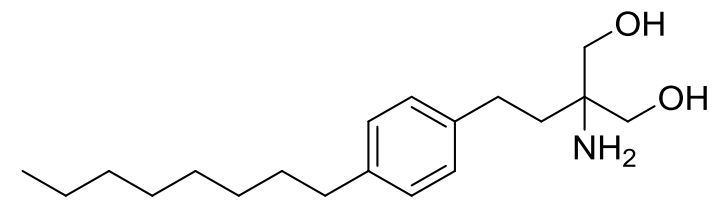

Fingolimod (18) 


\subsection{Mushroom Immunomodulators:}

The immunomodulating effects of mushroom metabolites are especially valuable in the prophylaxis as a mild and non-invasive form of a treatment, which can even prevent the proliferation of metastatic tumors, and is used as a co-treatment in combination with classic chemo- and radiotherapies (Wasser, 2002). The most potent immunomodulators produced by mushrooms belong to the lectins, terpenoids and polysaccharides.

\subsubsection{Lectins:}

The immunomodulatory activities of lectins (highly glycolylated proteins with specific binding capacities) from different organisms have been known for decades. Mushroom lectins are characterized by their particular antiproliferative and antitumor activities (Enshasy, 2011). Two lectins, TML-1 and TML-2, with immunomodulatory and antitumor activities were isolated from Tricholoma mongolicum (Wang et al., 1996).

\subsubsection{Terpenoids:}

Terpenes are built up of isoprene sub-units consisting of five carbon atoms. Among the huge number of terpenes, are special triterpenoids which are exclusively found in certain macrofungi (mostly basidiomycetes) and are famous for their biological activities and medicinal properties. One example of such a triterpenoid compound is the highly oxidized lanostane (19) which can be isolated from wood-decay fungi of the families Polyporaceae and Ganodermaceae (e.g. Ganoderma lucidum). This and related compounds show different biological activities including anti-infective, cytotoxic and immunomodulating efficacy (Moradali et al., 2007).

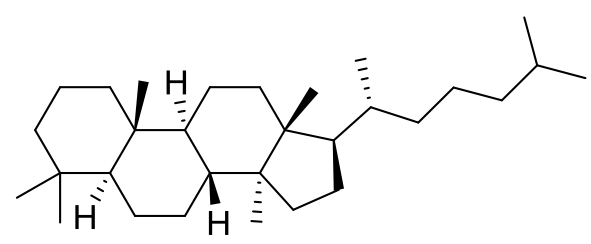

Lanostane (19)

Ganoderic, ganoderenic, ganodermic and applanoxidic acids, ganoderals, ganoderols, lucidone, ganodermanontriol as well as ganodermanondiol are the most common triterpenoids found in these mushrooms. Mixtures of these compounds can be prepared by the extraction of respective fruiting bodies with organic solvents. They were shown to have an antitumor activity that is comparable to that of certain $\beta$-d-glucans (see below). Fungal terpenoids can stimulate the NF-kB pathway and modulate Ras/Erk, c-myc and CREB proteins as well as mitogen-activated protein kinases. In consequence, these activation mechanisms can lead to other immune stimulations which are finally effective against tumor cells. 


\subsubsection{Polysaccharides:}

Mushroom derived polysaccharides are regarded as excellent immunostimulators due to their suitable therapeutic properties, i.e. they are barely toxic and have just negligible side-effects compared to other immunostimulants. Respective polysaccharides occur in relevant amounts in the macroscopic fruiting bodies and cultured mycelia but also to some extent in the culture filtrates of fungi (Leung et al., 2006). Grifola Frondosa polysaccharide-based drug was developed in China and approved as an adjunctive therapeutic drug for cancer treatment by the State Food and Drug Administration (SFDA) in 2010 (He et al., 2018).

The mushroom polysaccharides is non-specific immune system and thereby exert antitumor activities through the stimulation of the body's own defense mechanisms (Chang and Wasser, 2012). They can activate effector cells like macrophages and T-lymphocytes or prompt NK cells to secrete cytokines like TNF- $\alpha$, IFN- $\gamma$ and IL-1 $\beta$. In turn, some of these cytokines are able to directly promote the cytotoxicity of macrophages. The production of cytokines by immune cells can be considered as a key event in the initiation and regulation of the body's immune response (Lull et al., 2005).

\subsection{Quinazolines as immunomodulators:}

Quinazoline derivatives 20, 21 and 22a-d were reported to have immunomodulatory activity (Bennett et al., 1987).<smiles>O=C1CSC2=Nc3ccccc3CN12</smiles>

(20)<smiles>COC(=O)CC1SC2=Nc3ccccc3CN2C1=O</smiles>

(21)<smiles>[R]C(=O)/C=c1\sc2n(c1=O)Cc1ccccc1N=2</smiles>

$\left(22_{\text {a-d }}\right)$

\begin{tabular}{|c|c|}
\hline Compound & $\mathrm{R}$ \\
\hline $\mathbf{2 2}_{\mathbf{a}}$ & $\mathrm{NHCH}_{2} \mathrm{C}_{6} \mathrm{H}_{5}$ \\
\hline $\mathbf{2 2}_{\mathbf{b}}$ & $\mathrm{N}\left(\mathrm{CMe}_{3}\right) \mathrm{CH}_{2} \mathrm{C}_{6} \mathrm{H}_{5}$ \\
\hline $\mathbf{2 2}_{\mathbf{c}}$ & $\mathrm{OC}_{2} \mathrm{H}_{5}$ \\
\hline $\mathbf{2 2}_{\mathbf{d}}$ & $\mathrm{NHCH}_{2} \mathrm{CH}=\mathrm{CH}_{2}$ \\
\hline
\end{tabular}


Compound $\mathbf{2 3}$ has immunorestorative effects on the number of hematopoietic progenitor cells detected within spleen and bone marrow in immunosuppressed mouse model.<smiles>O=c1[nH]c2ccccc2c(=O)n1CCS</smiles>

(23)

In 2001, M. Tobe et al, synthesized and evaluated a series of quinazoline derivatives for the inhibitory activity against TNF- $\alpha$ production where compound $\mathbf{2 4}$ has a potent inhibitory activity against TNF- $\alpha$ production with $\mathrm{IC}_{50}=0.8 \mu \mathrm{M}$ (Tobe et al., 2001).

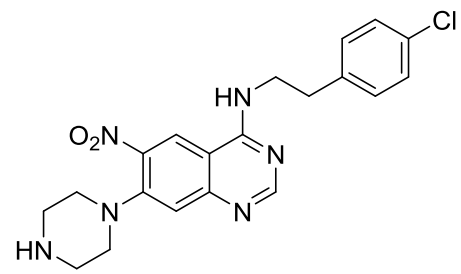

(24)

In 2015, $\mathrm{Pu}$ et al, showed that compound $\mathbf{2 5}$ exhibited an outstanding antiinflammatory activity and inhibition of TNF- $\alpha$ production with an $\mathrm{IC}_{50}$ of $8.86 \mu \mathrm{M}(\mathrm{Pu}$ et al., 2015).

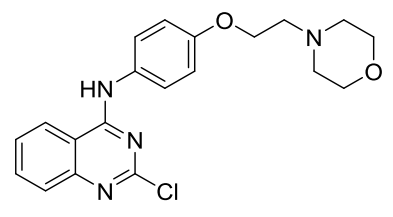

(25)

A series of quinazoline derivatives was designed, synthesized and screened for antiinflammatory activities. Compounds 26 and 27 demonstrated potent anti-inflammatory activities along with inhibition of both TNF- $\alpha$ and IL- 6 release with an $\mathrm{IC}_{50}$ of 2.8 and 3.4 $\mu \mathrm{M}$ (Hu et al., 2015).

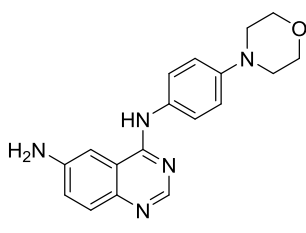

(26)

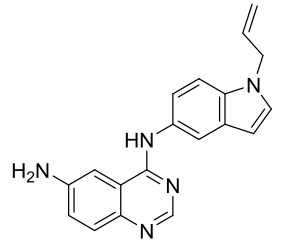

(27) 
In 2015, anti-inflammatory effects of 2-aryloxy-4-aminoquinazoline derivatives were evaluated. Compound $\mathbf{2 8}$ demonstrated a potent anti-inflammatory activity and significantly suppressed pro-inflammatory cytokines such as IL-6, IL-1 $\beta$ and TNF- $\alpha$. It exhibited antagonistic activity against protease activated receptor-2 (PAR2) with $\mathrm{IC}_{50}$ of $2.8 \mu \mathrm{M}$ (Cho et al., 2015).

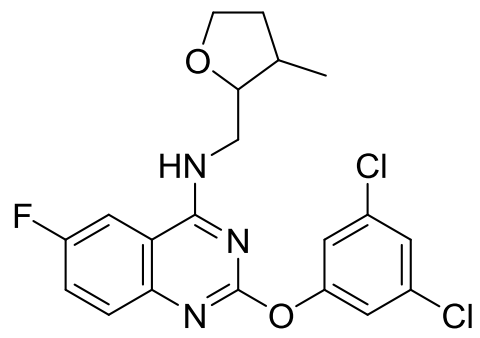

(28)

In 2019 Dolšak et al, synthesized a series of 2-(trifluoromethyl) quinazoline-4amine derivatives and evaluated their activity as a selective Toll-like receptor 7 agonists for treatment of viral infections, autoimmune diseases, and cancers. The results revealed that, compound (29) is most potent compound with $\mathrm{EC}_{50}$ of $4.4 \mathrm{Mm}$ (Dolšak et al., 2019).<smiles>CC(C)CNc1nc(C(F)(F)F)nc2ccccc12</smiles>

(29)

Kumar et al, synthesized a series of novel isoindolo[2,1-a]quinazoline derivatives as potent inhibitors of TNF- $\alpha$. The results revealed that, compound (30) is most potent compound and showed dose-depended inhibition with an $\mathrm{IC}_{50}$ value $9.33 \mathrm{mM}$ (Kumar et al., 2011b).<smiles>O=C1NC2c3ccccc3C(=O)N2c2ccccc21</smiles>

(30) 


\subsection{Lenalidomide derivatives as immunomodulators}

In 2017, Shengquan et al, synthesized a series of Lenalidomide derivatives as tumor angiogenesis inhibitor. The results indicate that the inhibitory activity $\mathrm{IC}_{50}$ of Lenalidomide was $340.3 \mu \mathrm{g} / \mathrm{mL}$ and the inhibitory activity $\mathrm{IC}_{50}$ of its derivatives $\mathbf{3 1}, \mathbf{3 2}$ and $\mathbf{3 3}$ were $261.8 \mu \mathrm{g} / \mathrm{mL}, 309.5 \mu \mathrm{g} / \mathrm{mL}$ and $225.2 \mu \mathrm{g} / \mathrm{mL}$, it shows that the Lenalidomide (2) derivatives have better inhibitory activity than Lenalidomide (Hu et al., 2017).

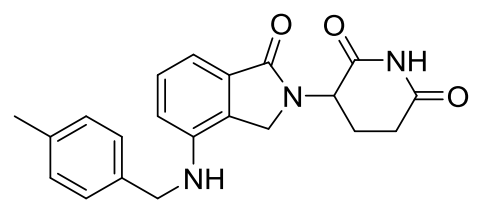

(31)

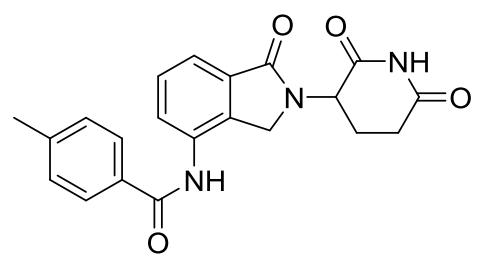

(32)

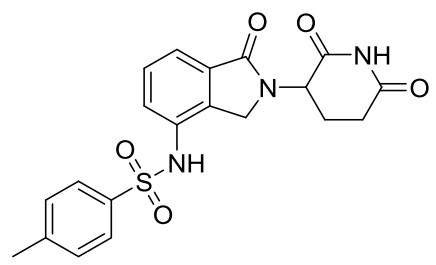

(33)

\section{Conclusion}

The immune system is a complex organ high specialized cells and even a circulatory system separate from blood vessels. The organ of the immune system poisoned throughout the body called lymphoid organ. Organ and the tissues of the immune system dot the body in a protective network of barrier to infection. Innate and adaptive immunity depends on the activity of white blood cells. Innate immunity largly depends upon granuolocyte and macrophages, while adaptive immune response depends upon lymphocytes, which provide long term immunity. Immunodeficiencies occur when one or more of the components of the immune system are inactive.

\section{REFERENCES:}

ABO-ZENA, R. A. \& HORWITZ, M. E. 2002. Immunomodulation in stem-cell transplantation. Current opinion in pharmacology, 2, 452-457.

ADACHI, K., KOHARA, T., NAKAO, N., ARITA, M., CHIBA, K., MISHINA, T., SASAKI, S. \& FUJITA, T. 1995. Design, synthesis, and structure-activity relationships of 2-substituted-2-amino-1, 3-propanediols: discovery of a novel immunosuppressant, FTY720. Bioorganic \& Medicinal Chemistry Letters, 5, 853856. 
ADEMOKUN, A. A. \& DUNN-WALTERS, D. 2010. Immune responses: primary and secondary. eLS.

ARYA, V. \& GUPTA, V. K. 2011. A review on marine immunomodulators. Int J Pharm Life Sci, 2, 751-758.

AZIZ, M., JACOB, A., YANG, W. L., MATSUDA, A. \& WANG, P. 2013. Current trends in inflammatory and immunomodulatory mediators in sepsis. Journal of leukocyte biology, 93, 329-342.

BARTLETT, J. B., DREDGE, K. \& DALGLEISH, A. G. 2004. The evolution of thalidomide and its IMiD derivatives as anticancer agents. Nature Reviews Cancer, 4, 314-322.

BECKER, H. 2007. Muromonab-CD3 (Orthoclone OKT3). Handbook of Therapeutic Antibodies, 905-940.

BENNETT, G. A., RADOV, L. A., TRUSSO, L. A. \& GEORGIEV, V. S. 1987. Synthesis and immunomodulating activity of 5H-thiazolo[2,3-b]quinazolin-3(2H)one. J Pharm Sci, 76, 633-4.

BILLIAU, A. \& MATTHYS, P. 2001. Modes of action of Freund's adjuvants in experimental models of autoimmune diseases. Journal of leukocyte biology, 70, 849-860.

BJORKLUND, C. C., KANG, J., AMATANGelo, M., POlOnSKAiA, A., KATZ, M., CHIU, H., COUTO, S., WANG, M., REN, Y. \& ORTIZ, M. 2020. Iberdomide (CC-220) is a potent cereblon E3 ligase modulator with antitumor and immunostimulatory activities in lenalidomide-and pomalidomide-resistant multiple myeloma cells with dysregulated CRBN. Leukemia, 34, 1197-1201.

BLOCKSIDGE, J., GLENN, M., GANDHI, A. K., KLIPPEL, A., POURDEHNAD, M., CHOPRA, R. \& KALAKONDA, N. 2014. CC-122 has robust antiproliferative activity in a primary chronic lymphocytic leukemia (CLL) co-culture model and is superior to lenalidomide. American Society of Hematology Washington, DC.

BOMFORD, R. 2010. Ethnomedicine: A Source of Complementary Therapeutics. Res. Signpost, 159, 227-244.

BONDY, G. S. \& PESTKA, J. J. 2000. Immunomodulation by fungal toxins. Journal of Toxicology and Environmental Health Part B: Critical Reviews, 3, 109-143. 
CERUNDOlO, V., SILK, J. D., MASRI, S. H. \& SALIO, M. 2009. Harnessing invariant NKT cells in vaccination strategies. Nature Reviews Immunology, 9, 2838.

CHANG, S. T. \& WASSER, S. P. 2012. The role of culinary-medicinal mushrooms on human welfare with a pyramid model for human health. Int J Med Mushrooms, 14, 95-134.

CHO, N. C., CHA, J. H., KIM, H., KWAK, J., KIM, D., SEO, S. H., SHIN, J. S., KIM, T., PARK, K. D., LEE, J., NO, K. T., KIM, Y. K., LEE, K. T. \& PAE, A. N. 2015. Discovery of 2-aryloxy-4-amino-quinazoline derivatives as novel proteaseactivated receptor 2 (PAR2) antagonists. Bioorg Med Chem, 23, 7717-27.

COLOMBO, D. \& AMMIRATI, E. 2011. Cyclosporine in transplantation - a history of converging timelines. J Biol Regul Homeost Agents, 25, 493-504.

COORDINATION, P. Cytotoxic Agents. The Pharmacological Basis of, 1677.

CRONSTEIN, B. N. \& AUNE, T. M. 2020. Methotrexate and its mechanisms of action in inflammatory arthritis. Nature Reviews Rheumatology, 16, 145-154.

DAR, O., KHAN, M. \& ADAGU, I. 2008. The potential use of methotrexate in the treatment of falciparum malaria: in vitro assays against sensitive and multidrugresistant falciparum strains. Japanese journal of infectious diseases, 61, 210-211.

DE-BLAnCO, E. J. C., PANDIT, B., HU, Z., SHI, J., LEWIS, A. \& LI, P.-K. 2007. Inhibitors of NF- $\mathrm{KB}$ derived from thalidomide. Bioorganic \& medicinal chemistry letters, 17, 6031-6035.

DOLŠAK, A., ŠVAJGER, U., LEŠNIK, S., KONC, J., GOBEC, S. \& SOVA, M. 2019. Selective Toll-like receptor 7 agonists with novel chromeno[3,4-d]imidazol-4(1H)one and 2-(trifluoromethyl)quinoline/ quinazoline-4-amine scaffolds. European Journal of Medicinal Chemistry, 179, 109-122.

DZURIS, J. L., BLOY, C., RUZEK, M. \& WILLIAMS, J. M. 2012. Transplantation Immunotherapy with Antithymocyte Globulin (ATG). : Immunotherapy in Transplantation. Wiley Online Library.

EL-ZAHABI, M. A., SAKR, H., EL-ADL, K., ZAYED, M., ABDELRAHEEM, A. S., EISSA, S. I., ELKADY, H. \& EISSA, I. H. 2020. Design, synthesis, and biological evaluation of new challenging thalidomide analogs as potential anticancer immunomodulatory agents. Bioorganic Chemistry, 104, 104218.

EL ENSHASY, H. 2011. Immunomodulators. Industrial Applications. Springer. 
ENSHASY, H. E. 2011. Immunomodulators. In: HOFRICHTER, M. (ed.) Industrial Applications. Berlin, Heidelberg: Springer Berlin Heidelberg.

FORD, M. \& ROACH, S. 2009. Introductory clinical pharmacology. USA: Lippincott Williams and Wilkins.

GOMbART, A. F., PIERRE, A. \& MAGgINI, S. 2020. A review of micronutrients and the immune system-working in harmony to reduce the risk of infection. Nutrients, $12,236$.

HAGNER, P., WANG, M., COUTO, S., BREIDER, M., FONTANILLO, C., TROTTER, M., BJORKLUND, C. C., HAVENS, C. G., RAYMON, H. K. \& NARLA, R. K. 2014. CC-122 has potent anti-lymphoma activity through destruction of the Aiolos and Ikaros transcription factors and induction of interferon response pathways. American Society of Hematology Washington, DC.

HAGNER, P. R., MAN, H.-W., FONTANILLO, C., WANG, M., COUTO, S., BREIDER, M., BJORKLUND, C., HAVENS, C. G., LU, G. \& RYCHAK, E. 2015. CC-122, a pleiotropic pathway modifier, mimics an interferon response and has antitumor activity in DLBCL. Blood, The Journal of the American Society of Hematology, 126, 779-789.

HE, Y., LI, X., HAO, C., ZENG, P., ZHANG, M., LIU, Y., CHANG, Y. \& ZHANG, L. 2018. Grifola frondosa polysaccharide: a review of antitumor and other biological activity studies in China. Discov Med, 25, 159-176.

HILL, N. \& SARVETNICK, N. 2002. Cytokines: promoters and dampeners of autoimmunity. Current opinion in immunology, 14, 791-797.

HONG, J. T., PARK, K. L., HAN, S. Y., PARK, K. S., KIM, H. S., OH, S. D., LEE, R. D. \& JANG, S. J. 2000. Effects of ochratoxin A on cytotoxicity and cell differentiation in cultured rat embryonic cells. Journal of Toxicology and Environmental Health Part A, 61, 609-621.

HOTCHKISS, R. S. \& NICHOLSON, D. W. 2006. Apoptosis and caspases regulate death and inflammation in sepsis. Nature Reviews Immunology, 6, 813-822.

HU, J., ZHANG, Y., DONG, L., WANG, Z., CHEN, L., LIANG, D., SHI, D., SHAN, X. \& LIANG, G. 2015. Design, Synthesis, and Biological Evaluation of Novel Quinazoline Derivatives as Anti-inflammatory Agents against Lipopolysaccharideinduced Acute Lung Injury in Rats. Chem Biol Drug Des, 85, 672-84. 
HU, S., YUAN, L., YAN, H. \& LI, Z. 2017. Design, synthesis and biological evaluation of lenalidomide derivatives as tumor angiogenesis inhibitor. Bioorganic \& medicinal chemistry letters, 27, 4075-4081.

INSTITUTE, N. C. 2021. immunomodulating agent [Online]. Available: https://www.cancer.gov/publications/dictionaries/cancerterms/def/immunomodulating-agent [Accessed].

ITO, T., ANDO, H., SUZUKI, T., OGURA, T., HOTTA, K., IMAMURA, Y., YAMAGUCHI, Y. \& HANDA, H. 2010. Identification of a primary target of thalidomide teratogenicity. science, 327, 1345-1350.

KEIFER, J. A., GUTTRIDGE, D. C., ASHBURNER, B. P. \& ALbERT JR, S. 2001. Inhibition of NF- $\kappa \mathrm{B}$ activity by thalidomide through suppression of I $\mathrm{B}$ kinase activity. Journal of Biological Chemistry, 276, 22382-22387.

KLATT, J., HARTUNG, H.-P. \& HOHLFELD, R. 2007. FTY720 (Fingolimod) als neue Therapiemöglichkeit der Multiplen Sklerose. Der Nervenarzt, 78, 1200-1208.

KLUEPFEL, D., KUDELSKI, A. \& BAGLI, J. 1975. Myriocin and process of preparation. Google Patents.

KÖNIG, S., PACE, S., PEIN, H., HEINEKAMP, T., KRAMER, J., ROMP, E., STRABBURGER, M., TROISI, F., PROSCHAK, A. \& DWORSCHAK, J. 2019. Gliotoxin from Aspergillus fumigatus abrogates leukotriene b4 formation through inhibition of leukotriene a4 hydrolase. Cell chemical biology, 26, 524-534. e5.

KRENSKY, M., BENNETT, M. \& VINCENTI, F. 2011. Immunosuppressants, tolerogens and immunostimulants. Brunton LL, 1005-31.

KUMAR, H., KAWAI, T. \& AKIRA, S. 2011a. Pathogen recognition by the innate immune system. International reviews of immunology, 30, 16-34.

KUMAR, K. S., KUMAR, P. M., KUMAR, K. A., SREENIVASULU, M., JAFAR, A. A., RAMBABU, D., KRISHNA, G. R., REDDY, C. M., KAPAVARAPU, R., SHIVAKUMAR, K., PRIYA, K. K., PARSA, K. V. \& PAL, M. 2011b. A new three-component reaction: green synthesis of novel isoindolo[2,1-a]quinazoline derivatives as potent inhibitors of TNF- $\alpha$. Chem Commun (Camb), 47, 5010-2.

KUSHWAHA, N. 2012. Immunomodulators as therapeutic agent. Journal of Drug Delivery and Therapeutics, 2. 
KYLES, A. E., GREGORY, C. R. \& CRAIGMILL, A. L. 2000. Comparison of the in vitro antiproliferative effects of five immunosuppressive drugs on lymphocytes in whole blood from cats. American journal of veterinary research, 61, 906-909.

LEUNG, M. Y., LIU, C., KOON, J. C. \& FUNG, K. P. 2006. Polysaccharide biological response modifiers. Immunol Lett, 105, 101-14.

LULL, C., WICHERS, H. J. \& SAVELKOUL, H. F. J. 2005. Antiinflammatory and Immunomodulating Properties of Fungal Metabolites. Mediators of Inflammation, 2005, 892572.

MAJUMDAR, S., LAMOTHE, B. \& AGGARWAL, B. B. 2002. Thalidomide suppresses NF- $\kappa$ B activation induced by TNF and $\mathrm{H} 2 \mathrm{O} 2$, but not that activated by ceramide, lipopolysaccharides, or phorbol ester. The Journal of Immunology, 168, 2644-2651.

MARIN, D. \& TARANU, I. 2015. Ochratoxin A and its effects on immunity. Toxin Reviews, 34, 11-20.

MATYSKIELA, M. E., ZHANG, W., MAN, H.-W., MULLER, G., KHAMBATTA, G., BACULI, F., HICKMAN, M., LEBRUN, L., PAGARIGAN, B. \& CARMEL, G. 2018. A cereblon modulator (CC-220) with improved degradation of Ikaros and Aiolos. Journal of medicinal chemistry, 61, 535-542.

MIZUNO, K., TSUJINO, M., TAKADA, M., HAYASHI, M., ATSUMI, K., ASANO, K. \& MATSUDA, T. 1974. Studies on bredinin. I Isolation, characterization and biological properties. The Journal of antibiotics, 27, 775-782.

MORADALI, M.-F., MOSTAFAVI, H., GHODS, S. \& HEDJAROUDE, G.-A. 2007. Immunomodulating and anticancer agents in the realm of macromycetes fungi (macrofungi). International immunopharmacology, 7, 701-724.

MUller, G. W., CHEN, R., HUANG, S.-Y., CORRAL, L. G., WONG, L. M., PATTERSON, R. T., CHEN, Y., KAPLAN, G. \& STIRLING, D. I. 1999. Amino-substituted thalidomide analogs: potent inhibitors of TNF- $\alpha$ production. Bioorganic \& medicinal chemistry letters, 9, 1625-1630.

NAFE, L. A., DODAM, J. R. \& REINERO, C. R. 2014. In-vitro immunosuppression of canine T-lymphocyte-specific proliferation with dexamethasone, cyclosporine, and the active metabolites of azathioprine and leflunomide in a flow-cytometric assay. Canadian Journal of Veterinary Research, 78, 168-175.

NAGA PREETHI, N. \& RAJESHWARI, P. Current Pharmaceutical \& Clinical Research. 
NAGATA, M. 2009. Immune-mediated Glomerular Injury. In: AVNER, E., HARMON, W., NIAUDET, P. \& YOSHIKAWA, N. (eds.) Pediatric Nephrology: Sixth Completely Revised, Updated and Enlarged Edition. Berlin, Heidelberg: Springer Berlin Heidelberg.

PARHAM, P. 2014. The immune system, Garland Science.

PU, Y., CAO, D., XIE, C., PEI, H., LI, D., TANG, M. \& CHEN, L. 2015. Anti-arthritis effect of a novel quinazoline derivative through inhibiting production of TNF- $\alpha$ mediated by TNF- $\alpha$ converting enzyme in murine collagen-induced arthritis model. Biochem Biophys Res Commun, 462, 288-93.

RAZZAGHI-ABYANEH, M., YOSHINARI, T., SHAMS-GHAHFAROKHI, M., REZAEE, M.-B., NAGASAWA, H. \& SAKUDA, S. 2007. Dillapiol and apiol as specific inhibitors of the biosynthesis of aflatoxin G1 in Aspergillus parasiticus. Bioscience, biotechnology, and biochemistry, 71, 2329-2332.

ROBERTS, C., SATOSKAR, A. \& ALEXANDER, J. 1996. Sex steroids, pregnancyassociated hormones and immunity to parasitic infection. Parasitology Today, 12, 382-388.

SAJID, M., IQBAL, Z., MUHAMMAD, G. \& IQBAL, M. 2006. Immunomodulatory effect of various anti-parasitics: a review. Parasitology, 132, 301.

SANO, H., NOGUCHI, T., TANATANI, A., HASHIMOTO, Y. \& MIYACHI, H. 2005. Design and synthesis of subtype-selective cyclooxygenase (COX) inhibitors derived from thalidomide. Bioorganic \& medicinal chemistry, 13, 3079-3091.

SAROJ, P., VERMA, M., JHA, K. \& PAL, M. 2012. An overview on immunomodulation. J Adv Sci Res, 3, 7-12.

SASAKI, S., HASHIMOTO, R., KIUCHI, M., INOUE, K., IKUMOTO, T., HIROSE, R., CHIBA, K., HOSHINO, Y., OKUMOTO, T. \& FUJITA, T. 1994. FUNGAL METABOLITES. PART $14 \uparrow$. NOVEL POTENT IMMUNOSUPPRESSANTS, MYCESTERICINS, PRODUCED BY Mycelia sterilia. The Journal of antibiotics, 47, 420-433.

SOMMERAUER, J. F., CHAMBERLAIN, A. R. \& HEMMELGARN, T. D. 2014. Pharmacology of immunosuppression. Pediatric Critical Care Medicine. Springer.

SPELMAN, K., BURNS, J., NICHOLS, D., WINTERS, N., OTTERSBERG, S. \& TENBORG, M. 2006. Modulation of cytokine expression by traditional medicines: a review of herbal immunomodulators. Alternative medicine review, 11, 128. 
SUGIYAMA, K., KAWADA, T., SATO, H. \& HIRANO, T. 2001. Comparison of suppressive potency between prednisolone and prednisolone sodium succinate against mitogen-induced blastogenesis of human peripheral blood mononuclear cells in-vitro. J Pharm Pharmacol, 53, 727-33.

SUSAN FM, S. R. Introductory Clinical Pharmacology. Lippincott Williams and Wilkins USA. 567-568.

SZEKERES-BARTho, J., BARAKONYI, A., PAR, G., POLGAR, B., PALKOVICS, T. \& SZEREDAY, L. 2001. Progesterone as an immunomodulatory molecule. International immunopharmacology, 1, 1037-1048.

TOBE, M., ISOBE, Y., TOMIZAWA, H., MATSUMOTO, M., OBARA, F., NAGASAKI, T. \& HAYASHI, H. 2001. Structure-activity relationships of quinazoline derivatives: dual-acting compounds with inhibitory activities toward both TNF-alpha production and T cell proliferation. Bioorg Med Chem Lett, 11, $545-8$.

TSUCHIYA, T., MATUOKA, A., SEKITA, S., HISANO, T., TAKAHASHI, A. \& ISHIDATE JR, M. 1988. Human embryonic cell growth assay for teratogens with or without metabolic activation system using microplate. Teratogenesis, carcinogenesis, and mutagenesis, 8, 265-272.

VIGUSHIN, D., MIRSAIDI, N., BROOKE, G., SUN, C., PACE, P., INMAN, L., MOODY, C. \& COOMBES, R. 2004. Gliotoxin is a dual inhibitor of farnesyltransferase and geranylgeranyltransferase I with antitumor activity against breast cancer in vivo. Medical oncology, 21, 21-30.

WANG, H., LIU, W., NG, T., OOI, V. \& CHANG, S. 1996. The immunomodulatory and antitumor activities of lectins from the mushroom Tricholoma mongolicum. Immunopharmacology, 31, 205-211.

WARD, C., CHILVERS, E. R., LAWSON, M. F., PRYDE, J. G., FUJIHARA, S., FARROW, S. N., HASLETT, C. \& ROSSI, A. G. 1999. NF- $\kappa B$ activation is a critical regulator of human granulocyte apoptosis in vitro. Journal of Biological Chemistry, 274, 4309-4318.

WASSER, S. 2002. Medicinal mushrooms as a source of antitumor and immunomodulating polysaccharides. Applied microbiology and biotechnology, 60, 258-274.

WEINER, L. M. 2015. Cancer immunology for the clinician. Clin Adv Hematol Oncol, 13, 299-306. 
WEISS, A. R. R. \& DAHLKE, M. H. 2019. Immunomodulation by mesenchymal stem cells (MSCs): mechanisms of action of living, apoptotic, and dead MSCs. Frontiers in immunology, 10, 1191.

YOKOTA, S. 2002. Mizoribine: mode of action and effects in clinical use. Pediatrics international, 44, 196-198.

YU, X. \& SUN, D. 2013. Macrocyclic drugs and synthetic methodologies toward macrocycles. Molecules, 18, 6230-6268.

$$
\begin{aligned}
& \text { المعلات المناعية الطيعية والاصطناعية ذات الانشطة البيولوجية المختلفة : فحص المنشورات } \\
& \text { العلمية والروئية التاريخية } \\
& \text { 'أنس رمضان عبد الستار ، *'محمد أيمن الذهبي ، 'عبد الله السيد عبد الله و'حازم القاضي } \\
& \text { 'قسم الكيمياء الدوائية الصيدلية وتصميم الأدوية ، كلية الصيدلة (بنين) ، جامعة الأزهر ، القاهرة ، مصر } \\
& \text { malzahaby@azhar.edu.eg : البريد الاكتروني للباحث الرئيسي }
\end{aligned}
$$

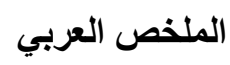

جهاز المناعة هو نظام معقد ومنطور للغاية ، ولكن مهمته بسيطة: البحث عن الغزاة وقتلهم. التعديل المناعي

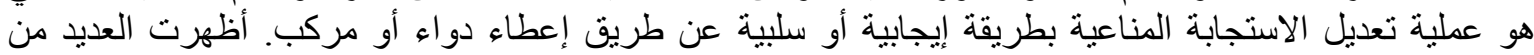

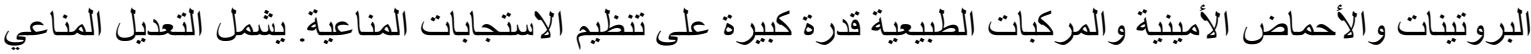

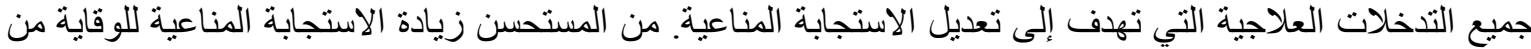

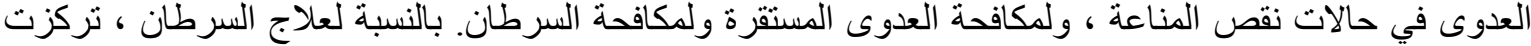

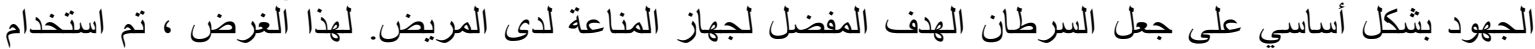

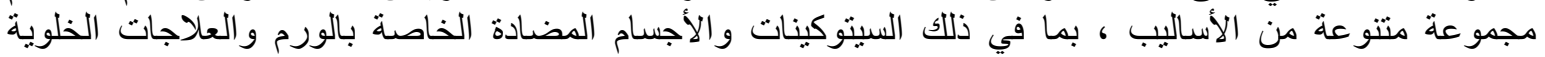

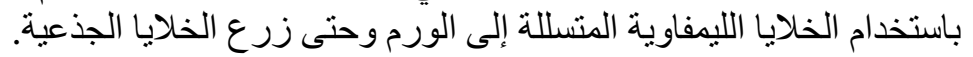

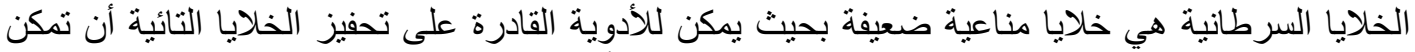

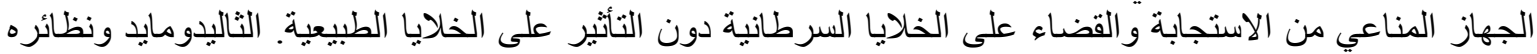

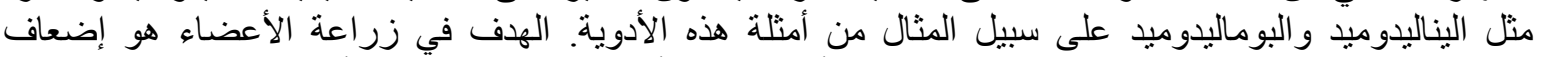

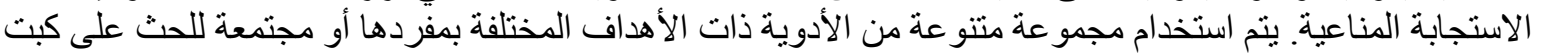

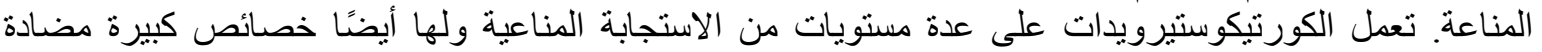

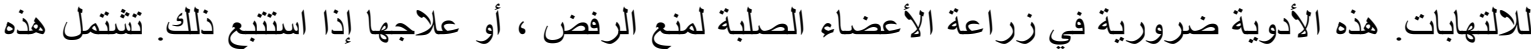

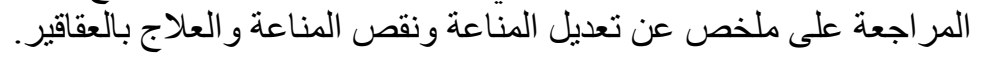

الكلمات المفتاحية: التحور المناعي ، مثبطات المناعة ، المنشطات المناعية ، الثاليدوميد ، المواد المساعدة للمناعة ، المناعة ، الجهاز المناعي ، زراعة الأعضاء العناء 